\title{
"MEASUREMENT OF PERFORMANCE AT INSTITUTIONS OF HIGHER LEARNING: THE BALANCED SCORE CARD APPROACH"
}

\author{
Anbalagan Krishnan \\ (anbalagan.k@curtin.edu.my) \\ Chan Kwok Mow \\ Jayaprakash Jeya Chandra Malar \\ Dr Junaid M. Shaikh \\ (Curtin University of Technology) \\ $\&$ \\ A/Prof Dr Abu Hassan Bin Md Isa \\ (University Sarawak Malaysia)
}

\begin{abstract}
$\underline{\text { Abstract }}$
Organizations have to confront with new developments brought about by the shift of industrial age competition to information age competition. As a result of this, certain assumptions with regard to the running and measurement of organizational performance have become obsolete. Information becomes essential to bring about new capabilities for competitive success. In the information age, it is vital for organizations to attempt to create future value through investments in customers, suppliers, employees, processes, technology and innovation (Kaplan, 1998). Therefore, in information age organizations need to formulate and utilise performance measurement tools that can be used to develop strategies, not only to create value for the current and future customers, but also to enhance current and future capabilities necessary to improve future performance. The tools are not only to be used to control behaviour and to evaluate past performances, but also to articulate and communicate future strategies. In brief, the objectives of this research study are:
\end{abstract}

1.Evaluate Performance Measurement at Institutions of Higher Learning

2.Assess the level of Awareness and knowledge of Balanced Scorecard as a measure

Keywords: Balanced Scorecard, Measures, Performance, Higher learning institutes, Approach 


\section{Introduction}

Increasingly higher educational institutions need to gain deeper insight into operations across many different faculties, divisions and critical business processes: - to budget, to plan and to manage more effectively. They are under continual pressure to find innovative, yet costeffective ways to organize, use, and share information to strengthen competitive advantage and improve the services they deliver to students. They need to find meaningful measurements, display recordable results and initiate actions based on the measurement results.

If they want to be effective and efficient, they need for instance, to track student recruiting and admissions, funding and means of improving financial performance and comparing academic performance. But more than these, institutions need to steer their performance in line with their mission, the strategic direction set, and evaluate performance in their internal processes, student and client management, financial returns and learning and growth.

This paper examines tools commonly used in performance measurement and assesses the knowledge and extent of awareness of the Balanced Scorecard (BSC) approach among the Higher Educational Institutions in Malaysia. In addition the focus is on the methodology used in the study which is driven by the two main objectives of the study. The two main objectives are:

1.Evaluate Performance Measurement at Institutions of Higher Learning

2.Assess the level of Awareness and knowledge of BSC as a measure

\section{Overview of the Malaysia Higher Education System}

Since the 1960s the limited capacity of the domestic higher education institution has rendered Malaysia to rely on the international higher educational resources to develop its human capital needs. Increasingly, privately sponsored students as well as government sponsored students were sent overseas to attain their higher education while efforts were also in place to expand the capacity of the domestic private and public institutions. For varying reasons, students tend to choose English speaking countries such as the US, UK, Australia, Canada and New Zealand as their study destination (Mazzarol and Soutar, 2002). The rapid economic growth experienced by Malaysia since 1980s is partly attributable to the heavy investment in developing its human resource capital as the economy became increasingly integrated with the economy of the rest of the world. During this period, private colleges and government institutions are beginning to mushroom around the country positioning them as the source of higher education.

In the 1990s, as the country was moving towards medium-to-high technology industries, further development and investment in skilled labour were required to provide the basis for the professional and technical skills required by the economy. The rising cost of overseas higher education as a result of the reform and the adoption of the user-pay concept in Western Universities have rendered the country to expedite the expansion of its domestic capability to meet its educational needs (Tan 2002). This led to the restructuring of the higher education sector in Malaysia through a plan to position Malaysia as the regional centre of educational excellence (Kasim 2001). This is described by Rudner (1998, p. 91 cited in Philips and Stahl 2002) as a "two-pronged strategy" that aims at expanding the domestic university and college systems to meet the domestic educational needs, as well as opening up Malaysia to 
participate in the international trade in higher education services. Towards this end, the Malaysian government has enacted six Acts within the two years, 1995 to 1997 to reform the overall education sector (The Malaysian Education System: Overview of Public and the private Education, 2004) These Acts are:

- The Education Act, 1996

- The Private Higher Educational Institutions Act, 1996

- National Council on Higher Education Act, 1996

- National Accreditation Board Act, 1996

- Universities and University Colleges (Amendment) Act, 1996

- National Higher Education Fund Board Act, 1997

Prior to the restructuring, the Malaysian higher education sector has been characterized only by the private colleges and government institutions. As a result of these Acts, the postrestructuring period of the higher education sector in Malaysia saw the establishment of private universities and branch campuses of foreign universities. A number of private colleges were allowed by the government to offer full foreign university degree programs. These Acts also allowed for the recruitment of foreign students as well as teaching staff. This was to ensure that these institutions could produce a competent workforce equipped with the skills, knowledge, attitude and behaviour to meet the demands of the high-technology era as well as internationally recognized qualification. This period effectively saw the Malaysian higher education sector characterized by categories of institutions namely private colleges, private universities and public institutions.

Balanced Scorecard Card and the implications of performance measurement in higher education sector

The concept of the BSC was first introduced by Robert S. Kaplan and David P. Norton (1992) in their now widely cited Harvard Business Review article, " The Balanced ScorecardMeasures that Drive Performance” ( Demetrius et al. 2005, pg. 222). The BSC is primarily developed to remove the drawback of the traditional performance assessment such as the traditional system which does not link to the firm's strategy; and to satisfy the need of performance measurement and management in the knowledge-based economy era. Kaplan and Norton developed the BSC concept after gathering opinions from researchers and business practitioners, and performed a study of future performance assessment system in technology research industry, traditional industry, and service industry (Hsu, 2005). The BSC views organizational performance from four dimensions (Hoque et al. 2000):

Financial perspectives- includes profitability measures such as operating income, return-on-capital-employed, sales growth, generation of cash flow, or economic value added;

Customer perspective- encompasses such measures as customer satisfaction, customer retention, new customer acquisition, customer response time, market share, and customer profitability;

Internal-business-processes perspective- the key measures include product design, product development, post-sale service, manufacturing efficiency, quality etc; and

Learning and growth perspective - measures the ability of employees, information systems, and organizational procedures to manage the business and adapt to change.

A critical factor of an effective BSC is the alignment of all the measures in the four perspectives with the company's vision and strategic objectives (Demetrius et al. 2005). 
According to the author, Kaplan and Norton noted that the BSC allows managers to track short-term financial results while simultaneously monitoring their progress in building the capabilities and acquiring the intangible assets that generate growth for future financial performance. Thus, the BSC enables managers to monitor and adjust the implementation of their strategies and to make fundamental changes in them.

Although the BSC initially was widely practiced by the manufacturing industry and business practice, the concept now is getting popular among the service industry such as education, banking and etc. Cullen, Joyce, Hassall, and Broadbent (2003) proposed that a BSC be used in educational institutions for reinforcement of the importance of managing rather than just monitoring performance (cited in Demetrius et al 2005). The BSC concept is already used by some of the universities to measure the academic and non academic performance. For instance Sutherland (2000) reported that at the Rossier School of Education at the University of Southern California adopted the BSC assess its academic program and planning process; Chang and Chow (1999) reported that responses in a survey of 69 accounting department heads were generally supportive of the BSC's applicability and benefits to accounting programs (cited in Demetrius et al 2005). Therefore, the concept of BSC, which was proposed by Kaplan and Norton (1992), is widely used by service industry to access their performance. Thus, the finding of this research provides valuable contribution to the theoretical knowledge of BSC usage and application in Malaysia in the educations sectors.

\section{$\underline{\text { Research Methodology and Design }}$}

This study will focus on Malaysian HEIs, both public and private, that offer at least academic programmes at the Diploma level. This included the following groups of institutions in the survey:

a. All public universities.

b. All public university colleges.

c. All local private universities.

d. All foreign universities.

e. All private university colleges.

f. All private colleges that have joint programs with local public universities.

g. 10 private colleges that have joint programs with foreign universities.

h. 10 private colleges that offer their own program which are accredited.

Total number of 338 questionnaires was sent out to the selected higher education institutions in Malaysia. The questionnaire was divided into four sections. Sections one and two test the first research objective and Sections three and four tested the second research objective of this study. Questionnaire relating to the four BSC perspectives were mailed to relevant officers and executives of private and public higher educational institutions in Malaysia. In addition, in an effort to ensure high response from the selected respondents, the members of the research team also conducted face-to-face interview with the selected officers

In order to achieve the first objective, the questionnaire included close-ended questions using a 10 - point Likert scale which was analysed to measure the extent to which BSC performance measurement mechanisms are used by the HEIs. The data collected was analysed using factor analysis, grouping the responses in accordance to the BSC perspectives. 
From the grouping it was assessed whether HEIs use the BSC mechanism as a performance measurement tool.

Further to this the study also identified indicators or drivers commonly used by HEIs to measure performance. The indicators used in the questionnaire are commonly cited in the literature related to this such as Kaplan (1998), Kaplan and Norton (1996), and Kaplan and Atkinson (1998).

The second objective, to test the knowledge and assess the awareness of BSC by HEIs, a list of true and false questions were used. Respondents were required to provide a response for each of the question. Percentage of correct responses was calculated for each respondent. The percentage will indicate the respondent's knowledge and awareness about BSC, where a high percentage score would indicate greater knowledge about the techniques and a low percentage score would mean lack of knowledge and awareness about the technique.

\section{$\underline{\text { Data Collection }}$}

The initial response rate was $12 \%$. Contributing to this poor response rate is the large number of questions in each section. In addition, some HEIs did not complete the questionnaire for reasons of confidentiality. The response rate improved when efforts were made by sending fax to all selected institutions, yet to respond to the questionnaire. At the final stage, a research assistant was employed to follow-up. These efforts increased total collection of completed questionnaires to 46 increasing overall response rate to $15 \%$.

Table 1 provides detail number of responded institution by category.

Table 1 : No of questionnaire collected as per category of institutions.

\begin{tabular}{|l|l|l|l|}
\hline Category of Institutions & $\begin{array}{l}\text { Total } \\
\text { Send out }\end{array}$ & Received & Rejected \\
\hline Public University & 9 & 2 & 1 \\
\hline Private University (Local) & 11 & 8 & 0 \\
\hline $\begin{array}{l}\text { Private University (Foreign } \\
\text { Branch) }\end{array}$ & 4 & 2 & 0 \\
\hline Public University College & 12 & 0 & 0 \\
\hline Private University College & 12 & 2 & 0 \\
\hline Private Colleges & 290 & 32 & 23 \\
\hline Total & 338 & 46 & 24 \\
\hline \% Received & & $14.65 \%$ & \\
\hline
\end{tabular}

\section{Data Analysis and Discussion}

The factor analysis for research objective one, the extent of the utilization of performance measure tools for financial perspective, shows that the HEIs use finance as a measure of their performance. Table 2 shows that the factor analysis of twenty items found five factors with eigen values greater than 1 . Factors One, Two and Three indicate that the higher education institution in Malaysia are using performance measurement tool to measure investment on resources, cost control and corporate funding. Factors Four and Five measure asset utilization and income from market segment as the measures of financial dimension. The 
research findings provide evidence that HEIs use the first perspective of BSC to evaluate whether strategies contribute to bottom-line improvement.

Table 2 - Financial Dimension

\begin{tabular}{|c|c|c|c|c|c|}
\hline \multirow{2}{*}{$\begin{array}{l}\text { MEASURES OF } \\
\text { DIMENSION }\end{array}$} & \multicolumn{5}{|c|}{ FACTORS } \\
\hline & 1 & 2 & 3 & 4 & 5 \\
\hline $\begin{array}{lr}\text { RESOURCES } & \text { FOR } \\
\text { ENHANCING } & \text { EXISTING } \\
\text { PRODUCTS } & \text { AND } \\
\text { SERVICES } & \end{array}$ & 0.874292 & & & & \\
\hline $\begin{array}{lr}\text { RESOURCES } & \text { FOR } \\
\text { DEVELOPING } & \text { NEW } \\
\text { PRODUCTS } & \text { AND } \\
\text { SERVICES } & \\
\end{array}$ & 0.815263 & & & & \\
\hline FUNDING FOR ICT & 0.759625 & & & & \\
\hline $\begin{array}{lr}\text { INVESTMENT } & \text { IN } \\
\text { MANAGEMENT } & \\
\text { SYSTEMS } & \text { AND } \\
\text { INFRASTRUCTURE } & \end{array}$ & 0.746241 & & & & \\
\hline $\begin{array}{lr}\text { CONTROLLING } & \text { COST } \\
\text { WITHOUT } & \\
\text { COMPROMISING } & \text { ON } \\
\text { ORGANIZATIONAL } & \\
\text { OBJECTIVES } & \end{array}$ & & 0.793645 & & & \\
\hline $\begin{array}{lr}\text { INESTMENTS } & \text { ON } \\
\text { INTELLECTUAL } & \text { AND } \\
\text { HUMAN CAPITAL } & \end{array}$ & & 0.676454 & & & -0.51614 \\
\hline \begin{tabular}{lrr} 
PROVISION & OF \\
RESOURCES IN & AND \\
SERVICES IN THE \\
\multicolumn{2}{l}{ VALUE FOR MONEY }
\end{tabular} & 0.472312 & 0.655714 & & & \\
\hline $\begin{array}{ll}\text { GOOD } & \text { FINANCIAL } \\
\text { STANDING } & \end{array}$ & & 0.605356 & & & \\
\hline $\begin{array}{ll}\text { NURTURING } & \text { AND } \\
\text { DEVELOPING } & \\
\text { CUSTOMER } & \\
\text { RELATIONSHIP } & \end{array}$ & & 0.488931 & & & 0.446217 \\
\hline $\begin{array}{l}\text { OBTAINING EXTERNAL } \\
\text { GRANTS FOR TRAINING } \\
\text { OPPOURTUNITES }\end{array}$ & & & 0.858442 & & \\
\hline $\begin{array}{l}\text { COMPARISON } \\
\text { OTHER HEI }\end{array}$ & & & 0.720896 & & \\
\hline $\begin{array}{l}\text { CORPORATE FUNDING } \\
\text { FOR STUDENTS }\end{array}$ & & & 0.703199 & & \\
\hline RESEARCH GRANT & & & 0.563926 & & -0.63719 \\
\hline $\begin{array}{l}\text { COST-EFFECTIVE } \\
\text { TEACHING AND } \\
\text { LEARNING METHOD }\end{array}$ & & & & 0.794358 & \\
\hline
\end{tabular}




\begin{tabular}{|c|c|c|c|c|}
\hline BUDGET MANAGEMENT & & & 0.684104 & \\
\hline $\begin{array}{l}\text { PRODUCTIVITY } \\
\text { IMPROVEMENT, ASSET } \\
\text { UTILIZATION AND RISK } \\
\text { MANAGEMENT }\end{array}$ & & & 0.601515 & \\
\hline $\begin{array}{l}\text { FINANCIAL } \\
\text { MEASUREMENT (ROCE, } \\
\text { OI \& GM) }\end{array}$ & 0.506264 & & 0.531529 & \\
\hline $\begin{array}{l}\text { INCREASE IN STUDENT } \\
\text { FEES }\end{array}$ & & 0.433359 & -0.56985 & 0.458292 \\
\hline $\begin{array}{lcl}\text { SALES } & \text { GRWOTH } & \text { IN } \\
\text { TARGETED MARKETS }\end{array}$ & & & & 0.656185 \\
\hline GROWTH IN REVENUES & & & & 0.605545 \\
\hline
\end{tabular}

As for customer perspective, table 3 below, shows how factor analysis grouped the performance tool into four factors. The first factor of customer perspective shows that the HEIs emphasis the student as their prime customers. Included in this measure are service level quality, costs and quality of delivery. The performance measurement tool on the first factor also indicates that the institutions emphasis on customer relationship which relates to the delivery of its services to the customers. The other three groups of factors indicate that the HEIs emphasis on image and reputation which enables an institution to proactively define itself for its customers. The result provides sufficient evidence that the HEIs use the second perspective of BSC to articulate unique customer and market-based strategies.

Table 3 - Customer Perspective

\begin{tabular}{|l|l|l|l|l|}
\hline \hline $\begin{array}{l}\text { EMPHASIS ON QUALITY } \\
\text { COURSE }\end{array}$ & 1 & 2 & 3 & 4 \\
\hline $\begin{array}{l}\text { EMPHASIZING ON CUSTOMER } \\
\text { SATISFACTION }\end{array}$ & 0.776545 & 0.443117 & & \\
\hline $\begin{array}{l}\text { ATTENDING TO THE NEEDS OF } \\
\text { STUDENTS }\end{array}$ & 0.749523 & & & \\
\hline $\begin{array}{l}\text { EMPHASIS ON QUALITY } \\
\text { INSTRUCTION }\end{array}$ & 0.732754 & 0.468682 & & \\
\hline SERVING STUDENTS THE LOCAL & 0.702381 & & 0.547909 & \\
\hline $\begin{array}{l}\text { SERVING } \\
\text { COMMUNICTY (PUBLIC) }\end{array}$ & 0.701852 & & & \\
\hline $\begin{array}{l}\text { EFFECTIENESS IN RETAINING } \\
\text { STUDENTS }\end{array}$ & 0.640164 & 0.467041 & & \\
\hline SERVING THE NATION ON AIVERSE & 0.485983 & 0.46039 & 0.474041 & \\
\hline $\begin{array}{l}\text { EMPHASIS ON } \\
\text { RANGE OF PROGRAMS } \\
\text { COURSES OFFERED. }\end{array}$ & & & & \\
\hline $\begin{array}{l}\text { EMPHASIS GAIN IN MARKET } \\
\text { SHARE }\end{array}$ & & 0.706472 & & \\
\hline $\begin{array}{l}\text { RECOGNITION OF THE } \\
\text { IMPORTANT ROLE OF ALUMNI } \\
\text { AND ITS CONTRIBUTIONS TO } \\
\text { ORGANIZATIONAL GROWTH }\end{array}$ & & & & \\
\hline
\end{tabular}




\begin{tabular}{|c|c|c|c|c|}
\hline $\begin{array}{lcc}\text { EMPHASIS } & \text { ON } & \text { THE } \\
\text { SATISFACTION } & \text { OF } & \text { THE } \\
\text { EMPLOYERS } & \text { OF } & \text { OUR } \\
\text { GRADUATES } & & \\
\end{array}$ & 0.601975 & 0.604873 & & \\
\hline $\begin{array}{lcr}\text { SERVING } & \text { THE } & \text { INDUSTRY } \\
\text { (PRIVATE SECTOR) } & \\
\end{array}$ & & & 0.820263 & \\
\hline $\begin{array}{lr}\text { SERVING } & \text { THE } \\
\text { SHAREHOLDERS/STAKEHOLDER }\end{array}$ & & & 0.761449 & \\
\hline $\begin{array}{l}\text { ATTENDING TO THE NEEDS OF } \\
\text { PARENTS }\end{array}$ & & & & 0.798275 \\
\hline $\begin{array}{l}\text { ATTENDING TO THE NEEDS OF } \\
\text { RESEARCH AND CONSULTANCY } \\
\text { CLIENTS }\end{array}$ & 0.411273 & & & 0.768006 \\
\hline $\begin{array}{l}\text { SERVING THE INTERNATIONAL } \\
\text { COMMUNITY }\end{array}$ & & 0.439881 & & 0.570987 \\
\hline
\end{tabular}

The third perspective, internal business process has great impact on customer satisfaction and achievement of an institution's financial objectives. The main business processes include innovation, operations and post service. Innovation stresses on long-term development and creation of new products and services. The operations process is related to the existing products and services and delivery to existing customers. The process stresses on efficient, consistent and timely delivery of existing services to existing customers. Post-service process refers to the services rendered to customers after the original delivery of services. As for the internal business perspective the factor analysis grouped the measurement tool into four groups. This factor indicates that the higher education institution includes performance measurement tool that evaluate the main business process that include innovations (Factor 1), operations (Factor 2 and 3) and post-service (Factor 4). Therefore, the research provides evidence that the HEIs use some form of performance measurement mechanism and emphasis on the three aspects of the internal business process.

Table 4 - Internal Business Perspective

\begin{tabular}{|c|c|c|c|c|}
\hline & $\bar{~} 1$ & 2 & 3 & 4 \\
\hline $\begin{array}{l}\text { OPERATES } \\
\text { INNOVATIVELY }\end{array}$ & 0.848579 & & & \\
\hline $\begin{array}{lr}\text { EMPHASIS } & \text { ON } \\
\text { EXCELLENCE } & \text { IN } \\
\text { DEVELOPING } & \text { LEARNING } \\
\text { SKILLS } & \\
\end{array}$ & 0.840239 & & & \\
\hline $\begin{array}{l}\text { OPERATES EFFICIENTLY } \\
\text { AND EFFECTIVELY }\end{array}$ & 0.827116 & & & \\
\hline $\begin{array}{lr}\text { EMPHASIS } & \text { ON } \\
\text { EXCELLENCE } & \text { IN } \\
\text { ADMINISTRATIVE } & \text { AND } \\
\text { FACULTY } & \text { MEMBERS } \\
\text { PERFORMANCE } & \\
\end{array}$ & 0.816654 & & & \\
\hline $\begin{array}{lr}\text { DELIVERS INFORMATION } \\
\text { RESOURCES IN A TIMELY, } \\
\text { EFFICIENT } & \text { AND } \\
\text { ACCURATE MANNER } & \end{array}$ & 0.803014 & & & \\
\hline
\end{tabular}




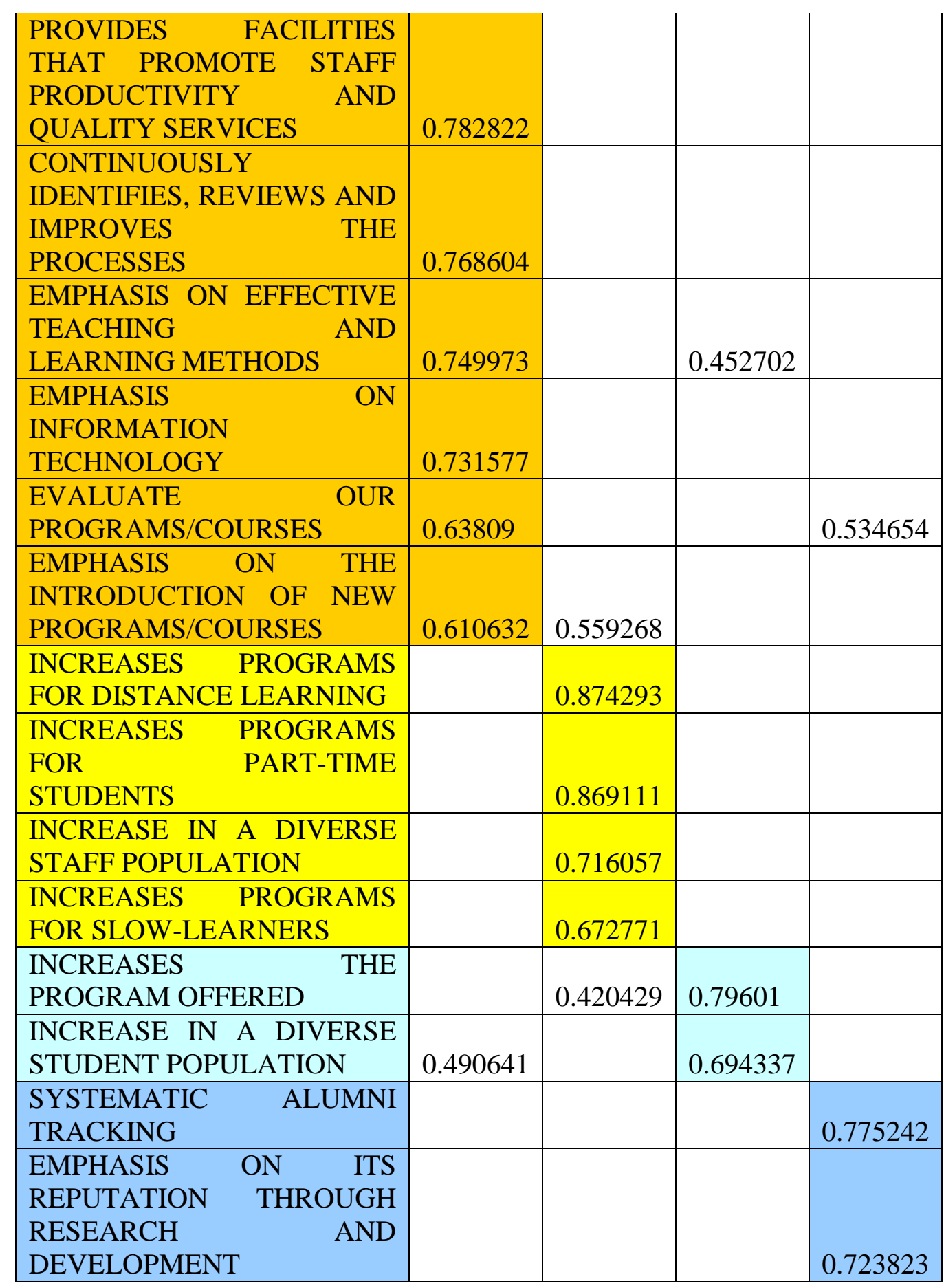

As for the last perspective, the result showed three factors for the learning and growth perspective. The three factors show that the higher education institutions uses performance measurement tool that concentrate on creating long term growth and improvements. The analysis provides evidence that the institutions employ certain form of performance mechanisms employed to assess the system and resource capabilities, such as the capabilities of the information system and employees. Based on the analysis, the group of performance measurement tool in factor one and two concentrate on assessing the innovation in teaching system and building the resource capabilities. As for the last factor the performance tools concentrate on innovation of programs offered by institutions. 
Table 5 - Innovation and Learning Growth Perspective

\begin{tabular}{|c|c|c|c|}
\hline & 1 & 2 & 3 \\
\hline $\begin{array}{l}\text { EMPHASIZES ON STAFF } \\
\text { DEVELOPMENT }\end{array}$ & 0.874125 & & \\
\hline $\begin{array}{lr}\text { FOCUSES ON } & \text { RECRUITING, } \\
\text { DEVELOPING } & \text { AND } \\
\text { RETAINING } & \text { QUALIFIED } \\
\text { STAFF } & \\
\end{array}$ & 0.873223 & & \\
\hline $\begin{array}{l}\text { DEVELOPS AND MAINTAINS } \\
\text { A CULTURE } \\
\text { ASSESSMENT }\end{array}$ & 0.825212 & & 0.417694 \\
\hline IN HOUSE TRAINING & 0.774147 & & \\
\hline $\begin{array}{l}\text { CONTINUOUSLY UPGRADES } \\
\text { PROGRAMS/COURSES TO } \\
\text { MEET NEW DEMANDS }\end{array}$ & 0.727929 & 0.579221 & \\
\hline $\begin{array}{l}\text { ENCOURAGE } \\
\text { COOPERATIVITY, } \\
\text { INNOVATION }\end{array}$ & 0.726492 & & 0.428087 \\
\hline $\begin{array}{l}\text { EMPHASIZES ON REGULAR } \\
\text { CURRICULUM REVIEW }\end{array}$ & 0.718731 & 0.406072 & \\
\hline $\begin{array}{l}\text { ADAPTS TO CHANGES IN } \\
\text { CIRCUMSTANCES, SERVICE } \\
\text { REQUIREMENTS AND NEW } \\
\text { PROGRAMS }\end{array}$ & 0.68512 & 0.553738 & \\
\hline $\begin{array}{l}\text { EMPHASIS ON INNOVATIVE } \\
\text { TEACHING AND LEARNING } \\
\text { METHODS }\end{array}$ & 0.665014 & 0.486175 & \\
\hline $\begin{array}{l}\text { INCREASES } \\
\text { KNOWLEDGE } \\
\text { TO THE LOCAL AND } \\
\text { INTERNATIONAL } \\
\text { COMMUNITIES }\end{array}$ & & 0.718271 & \\
\hline INNOVATION AND GROWTH & & 0.718225 & 0.516444 \\
\hline $\begin{array}{l}\text { NO OF UNITS/SUBJECTS } \\
\text { USING INTERNET IN T\&L }\end{array}$ & & 0.714641 & \\
\hline $\begin{array}{lr}\text { USES } & \text { PERFORMANCE } \\
\text { MEASUREMENT TOOLS FOR } \\
\text { FUTURE } & \text { STRATEGIC } \\
\text { PLANNING } & \end{array}$ & 0.505569 & 0.617404 & \\
\hline $\begin{array}{l}\text { EMPHASIZES ON DISTANCE } \\
\text { LEARNING }\end{array}$ & & & 0.840256 \\
\hline $\begin{array}{l}\text { EMPHASIZES ON THE LEVEL } \\
\text { OF RESEARCH }\end{array}$ & 0.469899 & & 0.649576 \\
\hline $\begin{array}{l}\text { EMPHASIZES ON } \\
\text { CONSULTANCY SERVICES }\end{array}$ & & 0.550467 & \\
\hline
\end{tabular}

The second objective of the study is to assess the level of knowledge and awareness among the HEIs. The analysis as shown in Table 6 below reveals that the awareness of using BSC approach is high. The findings support and complement the first objective. This means that 
HEIs are aware of the BSC approach as a performance measurement tool. This is evidenced by the research finding as shown in Table 6 below, that majority of respondents selected to strongly agree on their competency to use the BSC, its use at corporate level and departmental Level and the benefits of using the BSC.

Furthermore the table 6 below shows that BSC approach has not been in use for a very long time by the majority of HEIs (Code: $\mathrm{U}$ ). The finding also revealed that the development of this tool has not been outsourced to management consultant (Code: C). The reason for this could be that HEIs have in-house expertise to develop the institutions' performance measurement system using the BSC approach.

\section{Table 6: Assessment of awareness}

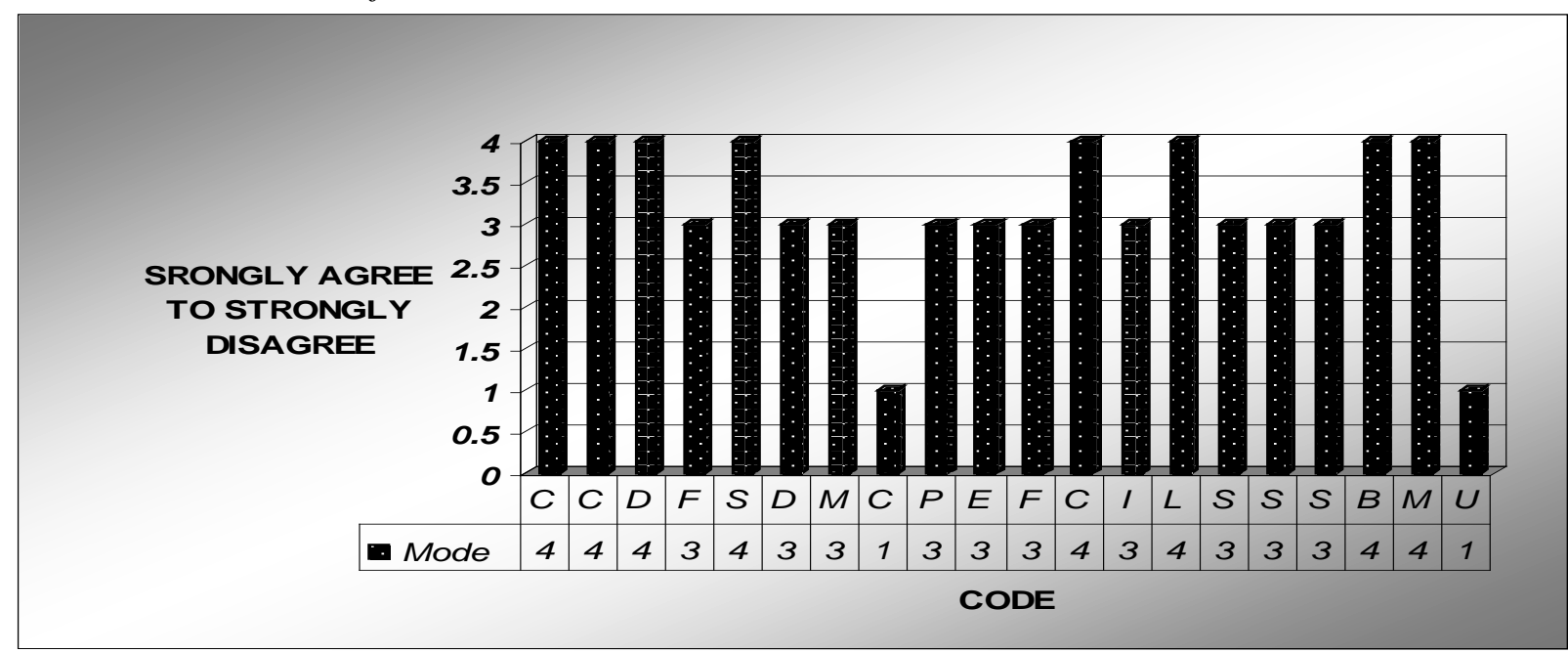

The above analysis is also supported by the finding on the level of knowledge of using BSC. As indicated in table 7 below, $89 \%$ of respondents correctly identified the positively supported statements and $71 \%$ supported the negatively supported statements about the BSC approach uses in measurement tool. This means the respondents have good knowledge about the BSC and are able to use BSC as the institution's performance measurement tool.

\section{Table 7 : Assessment of Knowledge}

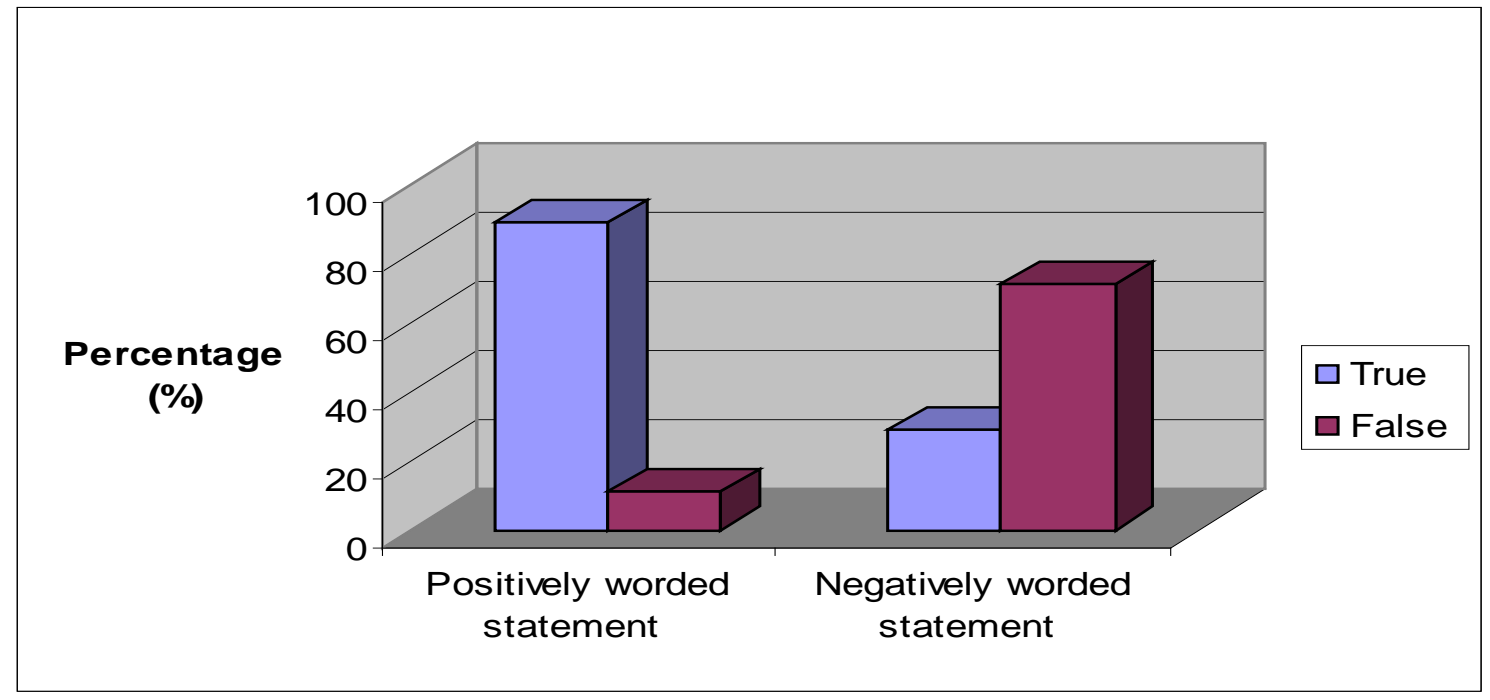




\section{Limitations}

This research required data to be collected from the various HEIs in Malaysia. Initially the questionnaire that was prepared had a total of nearly 300 questions. This total was reduced to 202 questions with comments and feedback received from focus groups who commented that the number of questions were too many for respondents. The research team feels now that even after scaling down, this number is too many and this could have contributed to the low response rate from participants in the survey.

Another limitation identified in this study is the likert scales used in some of the sections in this questionnaire. The choice given to respondents was to choose from 1-10. This was seen as too many as it created difficulty in defining each of these categories. It could have also provided with difficulty in the minds of respondents when selecting their responses. This further led to difficulties in creating the SPSS template when it was required to provide definition of variables and labeling responses.

\section{Conclusion \& Recommendations}

The research had two major objectives. The first objective of the research was to evaluate performance measurement at HEIs in Malaysia. The data analysis has provided evidence that HEIs use financial dimensions, customer satisfaction, internal process and learning and growth as part of their performance measurement tool.

The second objective was to assess the level of knowledge and awareness of BSC among HEIs in Malaysia. Again it is evident from the data analysis that there is a high level of awareness and knowledge of BSC among the HEIs. The research further reveals that majority of the HEIs develop their own performance measurement tool using the BSC approach. However, the research finding reveals that the usage of BSC is relatively new among HEIs.

The research team successfully completed the two research objectives. It recommends further research into the BSC model that will suggest its use for HEIs currently not using BSC and where applicable to improve its usage by HEIs currently using it.

\section{$\underline{\text { Reference List and Bibiliography }}$}

Atkinson, A A, Banker, R J, Kaplan, R S and Young, S M, 1997, Management Accounting, 2nd edition, Prentice-Hall, Upper Saddle River, New Jersey.

Agus Arawati, Sunita Barker, Jay Kandampully ,(2007), An exploratory study of service quality in the Malaysian public service sector ,International Journal of Quality \& Reliability Management; Volume: 24 , Issue: 2, Page: 177 -190

Bourne, M.,Franco, M. and Wilkes, J. (2003). Corporate performance management. Measuring Business Excellence 2003; 7, 3; p. 15.

Becker, B., Huselid, M., \& Ulrich, D. (2001). The HR scorecard: Linking people, strategy, and performance. Boston, MA: Harvard Business School Press. 
Chang, R. \& Morgan, M. (2000). Performance scorecards: Measuring the right things in the real world. San Francisco: Jossey-Bass.

Christopher D. Ittner and David F. Larcker, "Coming up Short on Nonfinancial Performance Measurement", Harvard Business Review, November 2003.

Demetrius,K. \& Patricia,K. (2005), ‘Applying the Balanced Scorecard to Education”, Journal of Education for Business, pp. 222- 230.

Eccles, R, 1991, ‘The Performance Measurement Manifesto’,Harvard Business Review, vol. 69, Jan-Feb, 131-137.

Eccles, R and Pyburn, P J, 1992, 'Creating a Comprehensive System to Measure Performance’, Management Accounting, vol. 74, no. 4, October, 41- 44.

Gubman E.L. (1996) The talent solution : Aligning strategy and people to achieve extraordinary results. McGraw-Hill, New York

Horngren, C T, Foster, G and Datar, S M, 1997, Cost Accounting: a Managerial Emphasis, Prentice-Hall. Horngren, C T, Bhimani,A, Foster, G and Datar, S M, 1999, Management and Cost Accounting, 10th edition, Prentice Hall,

Howard, R.,(2000) ,Overview of the Balanced Scorecard, by Howard Rohm, Founder \& Director, US Foundation for Performance Measurement, President, Howard Rohm Consultants, LLC. June 2000.

"Harvard Business Review Balanced Scorecard Report." Harvard Business Review , 2002 to present (bimonthly).

Hoque, Z. and W. James. 2000. Linking the balanced scorecard measures to size and market factors: Impact on organizational performance. Journal of Management Accounting Research (12): 1-17.

Hair, J.F., Rabin, B.M., \& Samouel, P., 2003, Essentials of Business Research.Hoboken, Wiley, NJ.

Hsu, K.H (2005), 'Using Balanced Scorecard and Fuzzy Data Envelopment Analysis for Multinational R\&D Project Performance Assessment', Journal of America Academy of Business, vol.7, no.1, pp.189- 196

Hoque,Z. \& James,W. (2000), 'Linking Balanced Scorecard Measures to Size and Market Factors: Impact on Organizational Performance’, Journal of Management Accounting Research, vol.12, pp.1- 17.

Kassim, A. (2001). Malaysia as a Centre of Education: Excellence: Experience and Plan, 15th Australian International Education Conference. 
Kaplan, R. \& Norton, D. (1996). The balanced scorecard. Boston, MA: Harvard Business School Press.

Kaplan, R.S. \& Atkinson, A.A., 1998, Advanced Management Accounting, Prentice-Hall, Singapore.

Kaplan, R.S. \& Norton, D.P., 1996, Translating Strategy into Action: The Balanced Scorecard, HBS Press, Boston.

Kaplan, R.S. \& Norton, D.P., 1998, The Balanced Scorecard - Measures that Drive Performance, Harvard Business Review on Measuring Corporate Performance, HBS Press, Boston.

Kaplan, R.S. \& Norton, D.P., 1998, Putting the Balanced Scorecard to Work, Harvard Business Review on Measuring Corporate Performance, HBS Press, Boston.

Kaplan, R.S. \& Norton, D.P., 1998, Using the Balanced Scorecard as a Strategic Management System, Harvard Business Review on Measuring Corporate Performance, HBS Press, Boston.

Kaplan, R S, 1983, 'Measuring Manufacturing Performance: a New Challenge for Managerial Accounting research', Accounting Review, vol. 58, no. 4, 686-705.

Kaplan, R.S. and D. P. Norton (1992) The Balanced Scorecard - Measures that Drive Performance, Harvard Business Review, Jan.-Feb. 1992, pp. 71-79.

KAPLAN R.S. \& NORTON D.P., The Balanced Scorecard -- Measures that Drive Performance, Harvard Business Review, Volume 70 No. 1, January-February, 1992, pp. 7179

Kaplan, R S and Norton, D P, 2001, 'Transforming the Balanced Scorecard from Performance Measurement to Strategic Management: Part 1', Accounting Horizons, March, pp.87-104.

Kaplan, R.S. and D. P. Norton (2005)"The Balanced Scorecard: Measures That Drive Performance", by Robert S. Kaplan and David P. Norton, Harvard Business Review, Jul/Aug 2005.

Mazzarol, T., \& Soutar, G. N. (2002). Push-pull factors influencing international student destination choice, The International Journal of Educational Management, 16(2), 82-90.

Nanni, A. J., J. R. Dixon and T. E. Vollman. 1992. Integrated performance measurement: Management accounting to support the new manufacturing realities. Journal of Management Accounting Research (4): 1-19.

Neely, Andy, (1999), 'The Performance Measurement Revolution: Why Now and What Next?', International Journal of Operations \& Production Management, vol. 19, no. 2, 205228. 
Norton D., Kaplan, R. (1992) The balanced scorecard:measures that drive performance, Harvard Business review, 70 (1).

Otley, D, 1999, 'Performance Management: a Framework for Management Control Systems research', Management Accounting Research, vol. 10, no .4, 363-382.

Phillips, M.W., \& Stahl, C.W. (2000). International Trade in Higher Education Srvicesin the Asia pacific Region: Trends and Issues, Pacific Economic Cooperation Council (PECC), Human Resource Development Task Force, $9^{\text {th }}$

Annual Meeting, 21-22 October, Hualien, Chinese Taipei.

Ruben, B.D., 2004, Pursuing Excellence in Higher Education, Jossey-Bass, San Francisco.

Tan, A.M. (2002). Malaysian Private Higher Education: Globalization, Privatization, Transformation and Marketplaces, Asean Academic Press, London.

The Malaysian Education System: Overview of Public and Private Education. (2004). Retrieved: March 12, 2008, from http://www.studymalaysia.com/is/smh4_chap1.shtml. 